the Caribbean; and three from Eastern Europe. The judges serve a term of nine years, with one third of the judges' terms expiring every three years.

Headquarters: Am Internationalen Seegerichtshof 1, D-22609

Hamburg, Germany.

Website: http://www.itlos.org

Registrar: Philippe Gautier (Belgium).

\section{International Union Against Cancer (UICC)}

Founded in 1933, the UICC is an international non-governmental association of 353 member organizations in 112 countries.

Objectives. The UICC is the only non-governmental organization dedicated exclusively to the global control of cancer. Its objectives are to advance scientific and medical knowledge in research, diagnosis, treatment and prevention of cancer, and to promote all other aspects of the campaign against cancer throughout the world. Particular emphasis is placed on professional and public education.

Membership. The UICC is made up of voluntary cancer leagues, patient organizations, associations and societies as well as cancer research and treatment centres and, in some countries, ministries of health.

Activities. The UICC creates and carries out programmes around the world in collaboration with several hundred volunteer experts, most of whom are professionally active in UICC member organizations. It promotes co-operation between cancer organizations, researchers, scientists, health professionals and cancer experts, with a focus in four key areas: building and enhancing cancer control capacity, tobacco control, populationbased cancer prevention and control, and transfer of cancer knowledge and dissemination. The next UICC World Cancer Congress is scheduled to take place in Montreal, Canada in 2012.

Address: 62 route de Frontenex, 1207 Geneva, Switzerland.

Website: http://www.uicc.org

President: Dr David Hill (Australia).

Executive Director: Cary Adams (UK).

\section{Inter-Parliamentary Union (IPU)}

Founded in 1889 by William Randal Cremer (UK) and Frédéric Passy (France), the Inter-Parliamentary Union was the first permanent forum for political multilateral negotiations. The Union is a centre for dialogue and parliamentary diplomacy among legislators representing every political system and all the main political leanings in the world. It was instrumental in setting up what is now the Permanent Court of Arbitration in The Hague.

Activities. The IPU fosters contacts, co-ordination and the exchange of experience among parliaments and parliamentarians of all countries; considers questions of international interest and concern, and expresses its views on such issues in order to bring about action by parliaments and parliamentarians; contributes to the defence and promotion of human rights-an essential factor of parliamentary democracy and development; contributes to better knowledge of the working and development of representative institutions and to the strengthening of representative democracy.

Membership. The IPU had 151 members and eight associate members in Feb. 2010.

Headquarters: Chemin du Pommier 5, C.P. 330, 1218

Le Grand Saconnex, Geneva 19, Switzerland.

Website: http://www.ipu.org

President: Theo-Ben Gurirab (Namibia).

Secretary-General: Anders B. Johnsson (Sweden).

\section{Interpol (International Criminal Police Organization)}

Organization. Interpol was founded in 1923, disbanded in 1938 and reconstituted in 1946. The International Criminal Police Organization-Interpol was founded to ensure and promote the widest possible mutual assistance between all criminal police authorities within the limits of the law existing in the different countries worldwide and the spirit of the Universal Declaration of Human Rights, and to establish and develop all institutions likely to contribute effectively to the prevention and suppression of ordinary law crimes.

Aims. Interpol provides a co-ordination centre (General Secretariat) for its 188 member countries. Its priority areas of activity concern criminal organizations, public safety and terrorism, drug-related crimes, financial crime and high-tech crime, trafficking in human beings and tracking fugitives from justice. Interpol centralizes records and information on international offenders; it operates a worldwide communication network.

Interpol's General Assembly is held annually. The General Assembly is the body of supreme authority in the organization. It is composed of delegates appointed by the members of the organization.

Interpol's Executive Committee, which meets four times a year, supervises the execution of the decisions of the General Assembly. The Executive Committee is composed of the president of the organization, the three vice-presidents and nine delegates.

Interpol's General Secretariat is the centre for co-ordinating the fight against international crime. Its activities, undertaken in response to requests from the police services and judicial authorities in its member countries, focus on crime prevention and law enforcement.

As of Feb. 2010 Interpol's Sub-Regional Bureaus were located in Abidjan, Buenos Aires, Harare, Nairobi, San Salvador and Yaoundé. Interpol's Liaison Office for Asia is located in Bangkok.

Headquarters: 200 Quai Charles de Gaulle, 69006 Lyon,

France.

Website: http://www.interpol.int

President: Khoo Boon Hui (Singapore).

\section{Islamic Development Bank}

The Agreement establishing the IDB (Banque islamique de développement) was adopted at the Second Islamic Finance Ministers' Conference held in Jeddah, Saudi Arabia in Aug. 1974. The Bank, which is open to all member countries of the Organization of the Islamic Conference, commenced operations 